\title{
Prediction of storability of organically produced paddy seeds through natural and accelerated ageing techniques
}

\author{
Gajendra Khidrapure $^{1 *}$, S. N. Vasudevan ${ }^{1}$, S. R. Doddagoudar ${ }^{1}$, A. G. Sreenivas ${ }^{2}$ and \\ Satyanarayana $\mathbf{R a o}^{3}$ \\ ${ }^{1}$ Department of Seed Science and Technology, University of Agricultural Science (UAS), Raichur-584104, INDIA \\ ${ }^{2}$ Department of Agricultural Entomology, UAS, Raichur-584104, INDIA \\ ${ }^{3}$ Department of Agronomy, Organic Farming Institute, UAS, Raichur-584104, INDIA \\ *Corresponding author. E-mail: gajumk@gmail.com
}

Received: January 21, 2016; Revised received: May 30, 2016; Accepted: July 24, 2016

\begin{abstract}
The present study was conducted to know the storage potential of organically produced paddy seeds in the Department of Seed Science and Technology, University of Agricultural Sciences, Raichur. The seed lot were divided into two parts, one part was stored in cloth bag for a period of 12 months under ambient conditions. At the same time another set of seeds were subjected to accelerated ageing at $42+1^{\circ} \mathrm{C}$ temperature and 90 per cent relative humidity $(\mathrm{RH})$ for a period of 0-12 days. Among the ageing methods, artificially aged seeds showed drastic decreases in seed quality as compared to natural ageing. Among the treatments $\mathrm{T}_{9}(37.5 \% \mathrm{FYM}+37.5 \%$ vermicompost $+25 \%$ neem cake + foliar spray of panchagavya on 30,60, 90 and 120 DAT) recorded significantly highest seed quality parameters viz., seed germination $(97.81 \%)$, seedling length $(29.42 \mathrm{~cm})$ and SVI $(2878)$ at initial stage in both the method of aging and at the end of storage period; seed germination (71.23 and $87.33 \%)$, seedling length $(19.66$ and $27.00 \mathrm{~cm}$ ) and SVI (1400 and 2358) in accelerated ageing (AA) and natural ageing (NA) respectively, whereas, lowest in control (Inorganic treatment). The seed quality parameters of four days of AA were similar to that of six months of NA. Hence, storability of organically produced paddy seeds were better as compared to inorganic seeds and it can be predicted that four days of $A A$ is equal to six months of NA. The information generated will be useful in retention or disposal of a particular variety or seed lot.
\end{abstract}

Keywords: Accelerated ageing, Natural ageing, Paddy, Prediction, Storability

\section{INTRODUCTION}

Seeds are uniquely equipped to survive as viable regenerative organisms until the time and place are right for the beginning of a new generation. However, like other forms of life, they cannot retain their viability indefinitely and eventually deteriorate and die. High quality seed shows no appreciable drop in germination (Vijayan, 2005). Standard germination test does not predict the extent of deterioration that occur in seeds, which is the sole deficiency of germination test for predicting relative storage potential of seeds (Shantappa Tirakannanavar et al., 2006). Many a time most of the seed producers (private or government organizations) will be forced to store a part of the seed produced may be because of excess production or due to less demand of the product. Under these circumstances, they will be put under confusion to take the decision or which seed lot need to be stored and which are need to be disposed off immediately. This emphasizes the need for a suitable technique through which we can assess the relative storability of seeds. Till date there is no widely accepted methods for measuring the relative storage potential of seed lot. However, stress test known as accelerated ageing test has been first developed by (Delouche, 1965) at Mississippi State University. Accelerated Ageing (AA) test show greater potential as a test for predicting the relative storability of different seed lots of crops (Desai, 1976). This test operate on the principle that under high temperature $\left(40-45{ }^{\circ} \mathrm{C}\right)$ and high relative humidity $(90-100 \%)$ conditions for short period, increases the catabolic changes at the cellular levels beyond the threshold of tolerance leading to reduction in seed quality parameters (Vasudevan et al., 2012). It is assumed that the process of deterioration under AA condition is same as in natural ageing (Delouche and Baskin, 1973). Hence, it is possible to predict the relative storability of a particular seed lot by exposing to high temperature and relative humidity for different durations and comparing the results with natural ageing. Keeping these in view an experiment was conducted with the objective of determining the storage potential of organically produced paddy seeds through accelerated ageing technique.

\section{MATERIALS AND METHODS}

Studies were undertaken at the Department of Seed Science and Technology, University of Agricultural 
Sciences, Raichur to know the storage potential of organically produced paddy seeds during 2013. Freshly harvested organically produced bulk seeds obtained from field experiment conducted by application of different nutrient treatments viz., $\mathrm{T}_{1^{-}}$control (RDF 100: 50: $\left.50 \mathrm{~kg} \mathrm{NPK} \mathrm{kg}^{-1} \mathrm{ha}\right), \mathrm{T}_{2}-100 \% \mathrm{RDN}$ through FYM , $\mathrm{T}_{3}-100 \%$ RDN through vermicompost (VC), $\mathrm{T}_{4}-50 \%$ RDN through FYM + $50 \%$ RDN through VC, $\mathrm{T}_{5}-37.5 \%$ RDN through FYM + $37.5 \%$ RDN through $\mathrm{VC}+25 \% \mathrm{RDN}$ through neem cake, $\mathrm{T}_{6}-\mathrm{T}_{2}+$ panchagavya@3\%, $\mathrm{T}_{7}-\mathrm{T}_{3}+$ panchagavya @ 3\%, $\mathrm{T}_{8^{-}}$ $\mathrm{T}_{4}+$ panchagavya @3\%, $\mathrm{T}_{9}-\mathrm{T}_{5}+$ panchagavya @3 $\%, \mathrm{~T}_{10}$-Green manuring (Organic farmer practices) and foliar spray of panchagavya at 30, 60, 90 and 120 days after transplanting. The seed lot of each treatment was divided into two parts out of which one part was subjected to accelerated ageing at $40+1{ }^{0} \mathrm{C}$ temperature and 98 per cent relative humidity $(\mathrm{RH})$ by keeping them in monolayer on a wire mesh for a period of 0-12 days (Delouche and Baskin, 1973). Accelerated aged samples were drawn at an interval of two day and subjected for different test to determine various quality parameters. At the same time sizable quantity of another part seeds were placed in cloth bag and stored for a period of 12 months and the observations on various seed quality parameters were recorded once in two months. The germination test was conducted in top of paper method (Anonymous, 2013). The seedling length of 10 randomly selected normal seedlings from germination test was measured from tip of shoot to root tip and the mean length was calculated and expressed as seedling length in centimeters. The seedling vigour index was determined by multiplying the percentage germination and total seedling length (Abdul-Baki and Anderson, 1973). The experiment was conducted in completely randomized design with four replication. The data obtained was statistically analysed as per (Panse and Sukhatme, 1978).

\section{RESULTS AND DISCUSSION}

There exist significant differences in the seed quality parameters (Tables 1-3) due to treatments (application of different sources of nutrients). The seed quality parameters viz., mean seed germination $(94.48 \%)$, seedling length $(27.29 \mathrm{~cm})$ and SVI (2578) were same at initial stage of ageing and decreased with advancement of storage period in both the ageing methods. Whereas, mean seed germination (67.95 and $82.79 \%$ ), seedling length (18.38 and $24.17 \mathrm{~cm}$ ) and SVI (1249 and 2001) were recorded at the end of AA and NA, respectively. Artificially aged seeds showed drastic decreases in seed quality as compared to natural ageing because of adverse effect of higher temperature and relative humidity leads to faster depletion of food reserves (Kovalenko et al., 1977); loss of membrane integrity, denaturation of protein and enzyme system and ultra structural changes (Roberts, 1972). Similar results were also observed by (Manimekalai, 2006) in black gram i.e. application of organics to seed and seed crop helps to increase seed quality by improving nutrient composition of seed and (Vijayan and Krishnaswamy, 2014) studied the impact of organic techniques of seed crop management on seed quality and reported that seed grown under organic condition recorded better quality as compared to inorganic method in paddy.

Among the treatments $\mathrm{T}_{9}(37.5 \% \mathrm{FYM}+37.5 \%$ vermicompost $+25 \%$ neem cake + foliar spray of panchagavya on 30, 60, 90 and 120 DAT) recorded significantly highest seed quality parameters viz., seed germination $(97.81 \%)$, seedling length $(29.42 \mathrm{~cm})$ and SVI (2878) at initial stage in both the method of aging. Whereas at the end of storage period; seed germination (71.23 and $87.33 \%$ ), seedling length (19.66 and 27.00 $\mathrm{cm})$ and SVI (1400 and 2358) in AA and NA respectively. The lowest seed germination (61.23 and 77.59 $\%)$, seedling length (15.29 and $19.92 \mathrm{~cm})$ and SVI (936 and 1546) in AA and NA respectively were recorded in inorganic treatment (RDF). The retention of higher germination potential may be due to initial vigour potential of resultant seeds $\left(\mathrm{T}_{9}\right)$. Better germination of seeds in the treatment $\left(\mathrm{T}_{9}\right)$ might be due to combined application of different sources of nutrients which helps to supply of both macro and micro nutrients there by better growth and development of plant. Panchagavya spray might also contribute for proper development of seed and virtue of its effect on enhancing the level of growth promoting substances in the seed brought out additional benefit there by increases in germination and vigour. Similar findings influence of organic manure on the plant growth and seed quality parameters in sesame and seed quality parameters of organic upland rice seed production was reported by (Vijayakumari and Hiranmai, 2012) and (Raumjit Nokkoul, 2014) respectively. The accelerated ageing

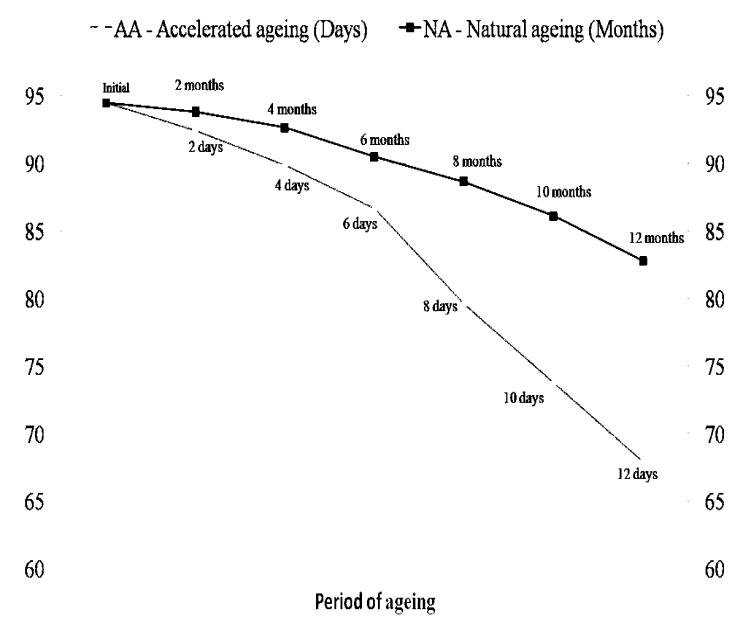

Fig.1. Prediction of relative storability of seeds though accelerated and natural ageing. 


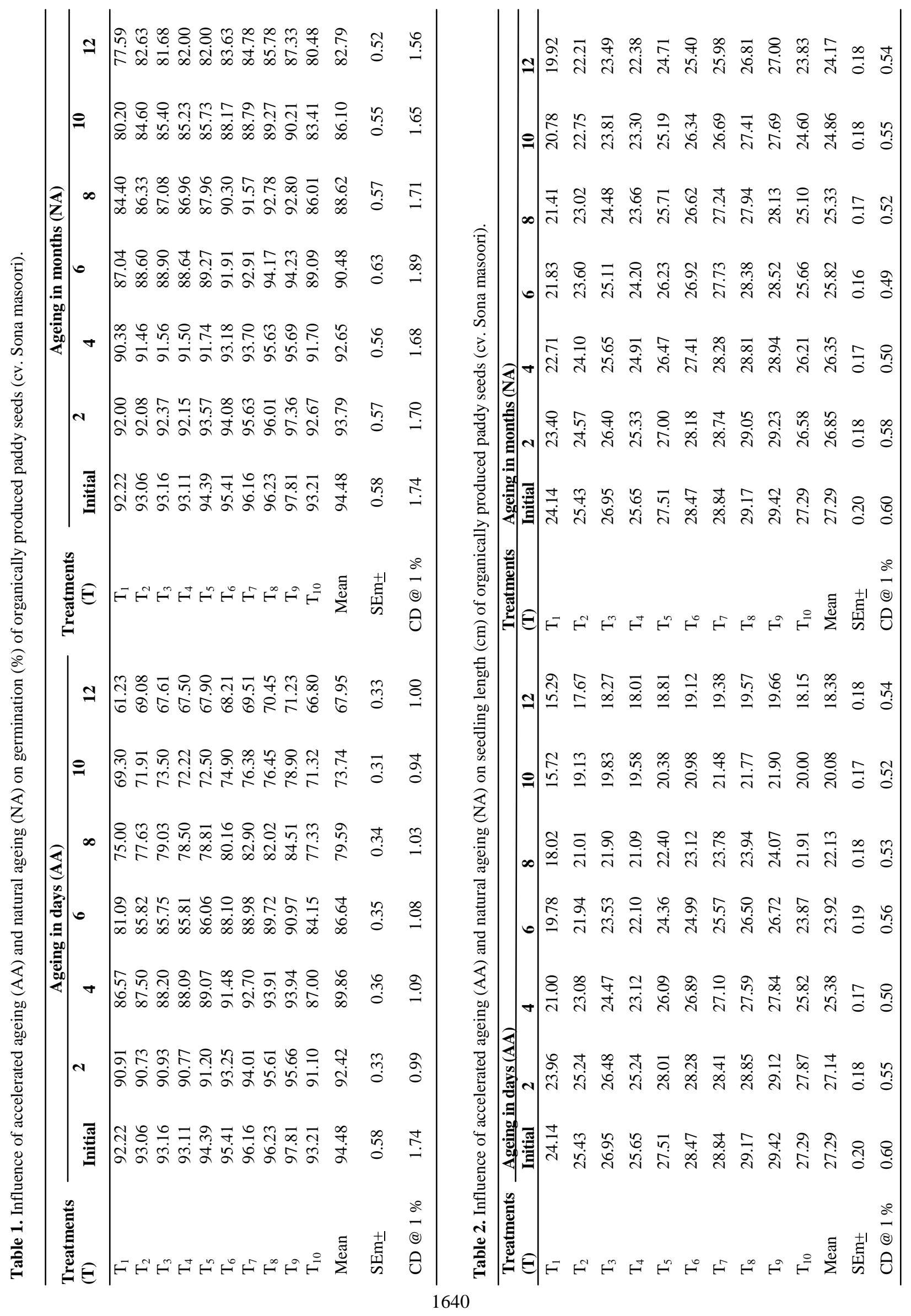


Gajendra Khidrapure et al. / J. Appl. \& Nat. Sci. 8 (3): 1638 - 1642 (2016)

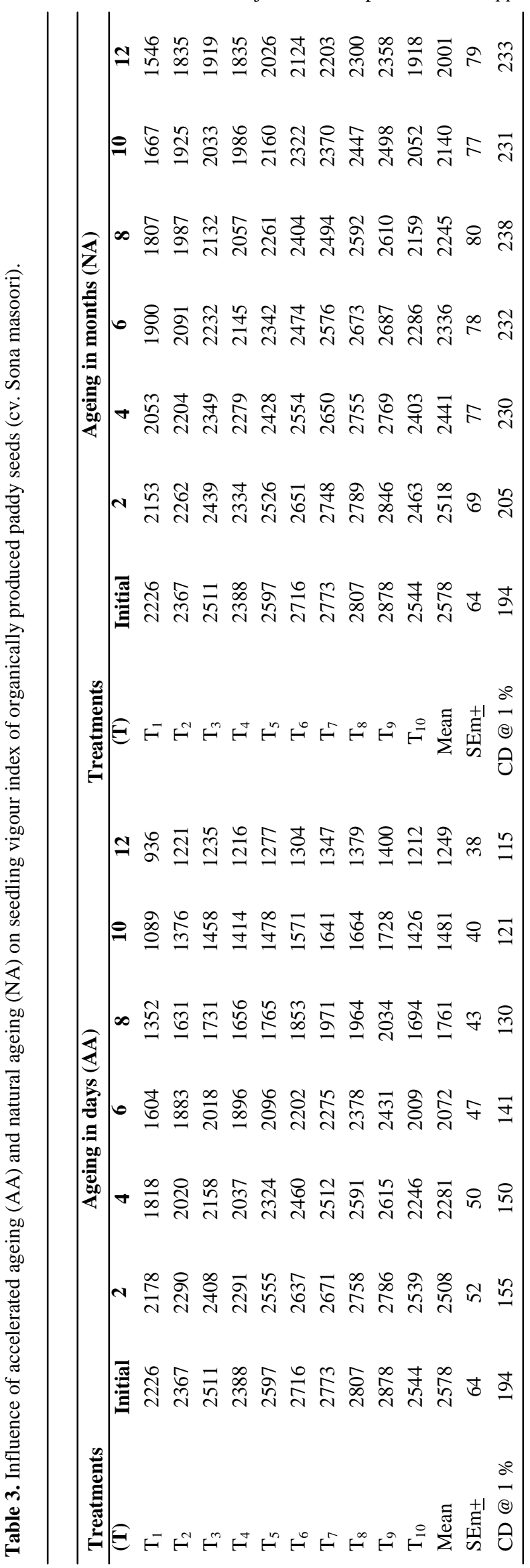

seems to be promising tool for evaluating the seed vigour and predicting relative storage potentiality. The results of accelerated ageing are almost similar to the results of natural ageing as evident by present study. The mean seed germination of four days of AA (89.86 $\%)$ was similar to that of six months of NA $(90.48 \%)$ as depicted in (Fig. 1). Similar result that is seed quality as influenced by accelerated and natural ageing in bitter gourd was reported by (Shantappa Tirakannanavar et al., 2006) and they predicted that seed quality deterioration in accelerated ageing was similar to that natural ageing except rate of deterioration.

\section{Conclusion}

From this study it was concluded that storability of organically produced paddy seeds were better (14 months) as compared to inorganic seeds (10 months) and it can be predicted that four days of accelerated ageing with mean seed germination (89.86) is equal to six months of natural ageing with mean seed germination (90.48).

\section{ACKNOWLEDGEMENTS}

The authors acknowledge the Department of Science \& Technology (DST), Government of India for providing INSPIRE fellowship, the Department of IT, BT and ST, VGST, GOK and Department of Seed Science \& Technology, UAS, Raichur for providing laboratory facilities to carry out research work.

\section{REFERENCES}

Abdul-Baki, A. A. and Anderson, J. D. (1973). Vigour determination in soybean seeds by multiple criteria. Crop Sci., 13: 630-633.

Anonymous (2013). International rules for seed testing, International Seed Testing Association (ISTA), Zurich, Switzerland. pp- 5-74.

Delouche, J. C. and Baskin, C. C. (1973). Accelerated ageing techniques for predicting the relative storability of seed lots. Seed Sci. and Technol., 1: 427-452.

Delouche, J. C. (1965). An accelerated ageing techniques for predicting the relative storability of crimson clover and tall fescue lots. Agron. Abst., $40: 50$.

Desai, D. B. ( 1976). Predicting the relative storability of seed lots. Seed Research, 4:62-65.

Kovalenko, G. I., Badev, D. and Falik, R. A., 1977, Some aspects of seed germination loss of cotton seed. Biol. Kishnask, 6: 26-30.

Manimekalai, C. (2006). Organic seed invigouration in black gram (Vigna mungo L.) cv. APK-1. M. Sc. (Agri.) Thesis, Tamil Nadu Agric. Univ., Coimbatore (India).

Panse, V. G. and Sukhatme, P. V. (1978). Statistical methods for agricultural workers, Indian Council of Agric. Res., New Delhi (India).

Raumjit Nokkoul (2014). Organic upland rice seed production. Advance Journal of Food Science and Technology, 6(12): 1313-1317.

Roberts, E. H. (1972). Loss of viability and crop yields. in: viability of seeds (Ed. E.H. Roberts), Chapman Hall 
Ltd., London, p. 313.

Shantappa Tirakannanavar, M. Shekhargouda, M. N. Merwade, Laxman Kukanoor and S. B. Bellad (2006). Seed quality as influenced by accelerated and natural ageing in bitter gourd (Momorrdica charantia L.). Seed Research, 34(1): 66-69.

Vasudevan, S. N., Shakuntala, N. M., Doddagoudar, S. R., Mathad, R. C. and Macha, S. I. (2012). Biochemical and molecular changes in aged peanut (Arachis hypogaea L.) seeds, The Ecoscan, 1: 347 - 352.

Vijayakumari, B. and Hiranmai, Y. R. (2012). Influence of fresh, composted and vermicomposted parthenium and poultry manure on the growth characters of sesame (Sesamum indicum). Journal of Organic Syst., 7(1): 14-19.

Vijayan, R. and Krishnaswamy, V. (2014). Impact of organic techniques of seed crop management on seed yield and quality in rice cv. ADT 43. Scientific Research and Essays, 9 (13): 611-618.

Vijayan, R. (2005). Organic seed production in rice cv. ADT 43, Ph.D. Thesis, Tamil Nadu Agric. Univ., Coimbatore (India). 